\title{
Synthesis, Electrochemical, Spectroscopic, Antimicrobial, and Superoxide Dismutase Activity of Nickel (II) Complexes with Bidentate Schiff Bases
}

\author{
R. N. Patel, ${ }^{1}$ S. P. Rawat, ${ }^{2}$ and Mukesh Choudhary ${ }^{3}$ \\ ${ }^{1}$ Department of Chemistry, A.P.S. University, Rewa 486003, India \\ ${ }^{2}$ Department of Chemistry, Govt. Vivekanand P.G. Collage Maihar, Satna 486755, India \\ ${ }^{3}$ Department of Chemistry, National Institute of Technology, Patna 800005, India \\ Correspondence should be addressed to Mukesh Choudhary; choudharydr.mukesh@yahoo.in
}

Received 19 August 2013; Revised 1 October 2013; Accepted 3 October 2013

Academic Editor: Rabindranath Mukherjee

Copyright (c) 2013 R. N. Patel et al. This is an open access article distributed under the Creative Commons Attribution License, which permits unrestricted use, distribution, and reproduction in any medium, provided the original work is properly cited.

\begin{abstract}
Five new nickel (II) complexes, namely, $\left[\mathrm{Ni}\left(\mathrm{L}^{1}\right)_{2}\right]\left(\mathrm{ClO}_{4}\right)_{2}(\mathbf{1}) ;\left[\mathrm{Ni}\left(\mathrm{L}^{2}\right)_{2}\right]\left(\mathrm{ClO}_{4}\right)_{2}(\mathbf{2})$; $\left[\mathrm{Ni}\left(\mathrm{L}^{3}\right)_{2}\right]\left(\mathrm{ClO}_{4}\right)_{2}(\mathbf{3})$; $\left[\mathrm{Ni}\left(\mathrm{L}^{4}\right)_{2}\right]\left(\mathrm{ClO}_{4}\right)_{2}(\mathbf{4})$; $\left[\mathrm{Ni}\left(\mathrm{L}^{5}\right)_{2}\right]\left(\mathrm{ClO}_{4}\right)_{2}(5)$, where $\mathrm{L}^{1}=$ benzoylhydrazide; $\mathrm{L}^{2}=\mathrm{N}-\left[(1)-1-(2\right.$-methylphenyl)ethylidene $]$ benzohydrazide; $\mathrm{L}^{3}=\mathrm{N}-[(1)-1-(4-$ methylphenyl)ethylidene]benzohydrazide; $\mathrm{L}^{4}=\mathrm{N}$-[(1)-1-(2-methoxyphenyl)ethylidene]benzohydrazide; $\mathrm{L}^{5}=\mathrm{N}$-[(1)-1-(4-methoxyphenyl)ethylidene]benzohydrazide, have been synthesized and characterized by various physicochemical and spectroscopic techniques. The synthesized complexes are stable powders, insoluble in common organic solvents such as ethanol, benzene, carbon tetrachloride, chloroform, and diethyl ether, and are nonelectrolytes. The magnetic and spectroscopic data indicate a distorted square planar geometry for all complexes. The superoxide dismutase activity of these complexes has been measured and discussed. Antibacterial and antifungal properties of these complexes were also tested.
\end{abstract}

\section{Introduction}

The synthesis of low molecular weight nickel (II) complexes mimicking superoxide dismutase (SOD) activity has been challenging for bioinorganic chemists and recently some complexes with high catalytic activity have been reported [1-3]. Nickel-containing superoxide dismutase (Ni-SOD) has been isolated from several Streptomyces species [4]. The enzymatic activity of Ni-SOD [5] is as high as that of $\mathrm{Cu}-\mathrm{Zn}$ SOD at about $10^{9} \mathrm{M}^{-1} \mathrm{~S}^{-1}$ per metal center. Oberley and Buettner [6] have reported that cancer cells had less superoxide dismutase (SOD) activity than normal cells. Superoxide ion is toxic to cells; a defense mechanism must have been initiated by nature. All organisms, which use dioxygen and many that have to survive an oxygenated environment, contain at least one SOD. The superoxide radical $\left(\mathrm{O}_{2}{ }^{-}\right)$is an inevitable byproduct of aerobic metabolism which if not eliminated may cause significant cellular damage and has been implicated in numerous medical disorders [7]. To avoid such harmful consequences, all oxygen metabolizing organisms possess metalloenzymes known as superoxide dismutases (SODs). These SODs disproportionate the toxic $\mathrm{O}_{2}{ }^{-}$radical to molecular oxygen and hydrogen peroxide $[8,9]$. All SODs employ the two-step Ping-Pong mechanism shown in

$$
\begin{gathered}
\mathrm{M}^{\mathrm{ox}}+\mathrm{O}_{2}^{-} \longrightarrow \mathrm{M}_{\mathrm{red}}+\mathrm{O}_{2} \\
\mathrm{M}_{\mathrm{red}}+\mathrm{O}_{2}{ }^{-}+2 \mathrm{H}^{+} \longrightarrow \mathrm{M}^{\mathrm{ox}}+\mathrm{H}_{2} \mathrm{O}_{2}
\end{gathered}
$$

where $\mathrm{M}$ is a redox active metal center capable of both oxidizing and reducing superoxide.

Metal complexes of bidentate Schiff bases have been extensively studied $[10,11]$, because such ligands can bind with one, two, or more metal centers involving various coordination modes and allow synthesis of homo- and heteronuclear metal complexes with interesting stereochemistry $[12,13]$. A number of papers $[14,15]$ highlight the flexible nature of bidentate ligands, their analytical, and biological properties. Recently, we have studied [16-18] various Schiff bases and their metal (II) complexes. This paper describes synthesis, electrochemical, spectroscopic, antimicrobial, 
and superoxide dismutase (SOD) activity of nickel (II) complexes namely $\left[\mathrm{Ni}\left(\mathrm{L}^{1}\right)_{2}\right]\left(\mathrm{ClO}_{4}\right)_{2}(\mathbf{1}),\left[\mathrm{Ni}\left(\mathrm{L}^{2}\right)_{2}\right]\left(\mathrm{ClO}_{4}\right)_{2}(\mathbf{2})$, $\left[\mathrm{Ni}\left(\mathrm{L}^{3}\right)_{2}\right]\left(\mathrm{ClO}_{4}\right)_{2}(3), \quad\left[\mathrm{Ni}\left(\mathrm{L}^{4}\right)_{2}\right]\left(\mathrm{ClO}_{4}\right)_{2}(4)$, and $\left[\mathrm{Ni}\left(\mathrm{L}^{5}\right)_{2}\right]$ $\left(\mathrm{ClO}_{4}\right)_{2}(5)$. All the Schiff bases $\left(\mathrm{L}^{2}, \mathrm{~L}^{3}, \mathrm{~L}^{4}\right.$, and $\left.\mathrm{L}^{5}\right)$ are bidentate ligand having donor site nitrogen and oxygen atom (Scheme 1). Superoxide dismutase activity of all these complexes has been revealed to catalyze the dismutation of superoxide $\left(\mathrm{O}_{2}{ }^{-}\right)$, and $\mathrm{IC}_{50}$ values were evaluated and discussed.

\section{Experimental}

2.1. Physical Measurements. Nickel (II) chloride hexahydrate was purchased from S. D. Fine-Chem Limited, India. All other chemicals used were of synthetic grade and used without further purification. Elemental analyses were performed on an Elementar Vario EL III Carlo Erba 1108 analyzer. FAB mass spectra were recorded on a JEOL SX 102/DA 6000 mass spectrometer data system using xenon $(6 \mathrm{kV}, 10 \mathrm{~mA})$ as the FAB gas. The accelerating voltage was $10 \mathrm{kV}$ and the spectra were recorded at room temperature. UV-Vis spectra were recorded at $25^{\circ} \mathrm{C}$ on a Shimadzu UV-Vis recording spectrophotometer UV-1601 in quartz cells. IR spectra were recorded in $\mathrm{KBr}$ medium on a Perkin-Elmer 783 spectrophotometer in the $4000-600 \mathrm{~cm}^{-1}$ region. Cyclic voltammetry was carried out with a BAS-100 Epsilon electrochemical analyzer having an electrochemical cell with a three-electrode system. $\mathrm{Ag} / \mathrm{AgCl}$ was used as a reference electrode, glassy carbon as working electrode, and platinum wire as an auxiliary electrode. $0.1 \mathrm{M} \mathrm{NaClO}_{4}$ was used as supporting electrolyte and DMSO as solvent. Molar conductivities of freshly prepared $2 \times 10^{-3} \mathrm{M}$ of acetonitrile solutions were measured on a Systronics conductivity TDS meter 308. The in vitro SOD activity was measured using alkaline DMSO as a source of superoxide radical $\left(\mathrm{O}_{2}{ }^{-}\right)$and nitroblue tetrazolium chloride (NBT) as $\mathrm{O}_{2}{ }^{-}$scavenger [19]. In general, $400 \mu \mathrm{L}$ sample to be assayed was added to a solution containing $2.1 \mathrm{~mL}$ of $0.2 \mathrm{~mol} \mathrm{~L}^{-1}$ potassium phosphate buffer $(\mathrm{pH} 8.6$ ) and $1 \mathrm{~mL}$ of $56 \mu \mathrm{mol} \mathrm{L}^{-1}$ alkaline DMSO solution prepared under similar condition in DMSO (except $\mathrm{NaOH}$ ). A unit of SOD activity is the concentration of complex, which causes 50\% inhibition of alkaline DMSO-mediated reduction of NBT. The in vitro antimicrobial (antibacterial) activities of these complexes were tested using paper disc diffusion method [20]; the chosen strains were Streptococcus aureus and Escherichia coli. The liquid medium containing the bacterial subcultures was autoclaved for $20 \mathrm{~min}$ at $121^{\circ} \mathrm{C}$ and at $15 \mathrm{lb}$ pressure before inoculation. The bacteria were then cultured for $24 \mathrm{~h}$ at $36^{\circ} \mathrm{C}$ in an incubator. The antifungal activity of the present complexes has been evaluated against Aspergillus sp. and Penicillium sp. by the Radial Growth Method [21] using Czapek's agar medium. The compounds were added directly with the medium in 5, 10 and $15 \mathrm{mM}$ concentrations.

2.2. Synthesis of $L^{2}, L^{3}, L^{4}$, and $L^{5}$. The Schiff bases $L^{2}, L^{3}$, $\mathrm{L}^{4}$, and $\mathrm{L}^{5}$ were prepared by general condensation reaction and recrystallized from ethanol or methanol. A methanol

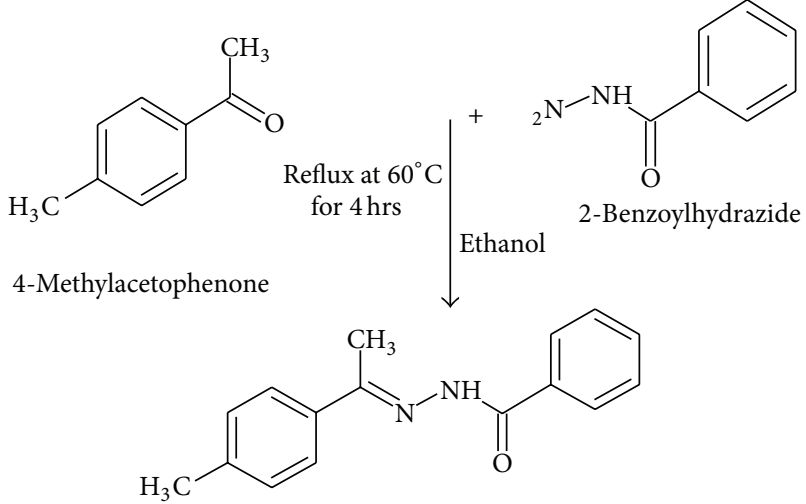

$\left(\mathrm{L}^{3}\right), \mathrm{N}-[(1)-1-(4-$ Methylphenyl)ethylidene]benzohydrazide

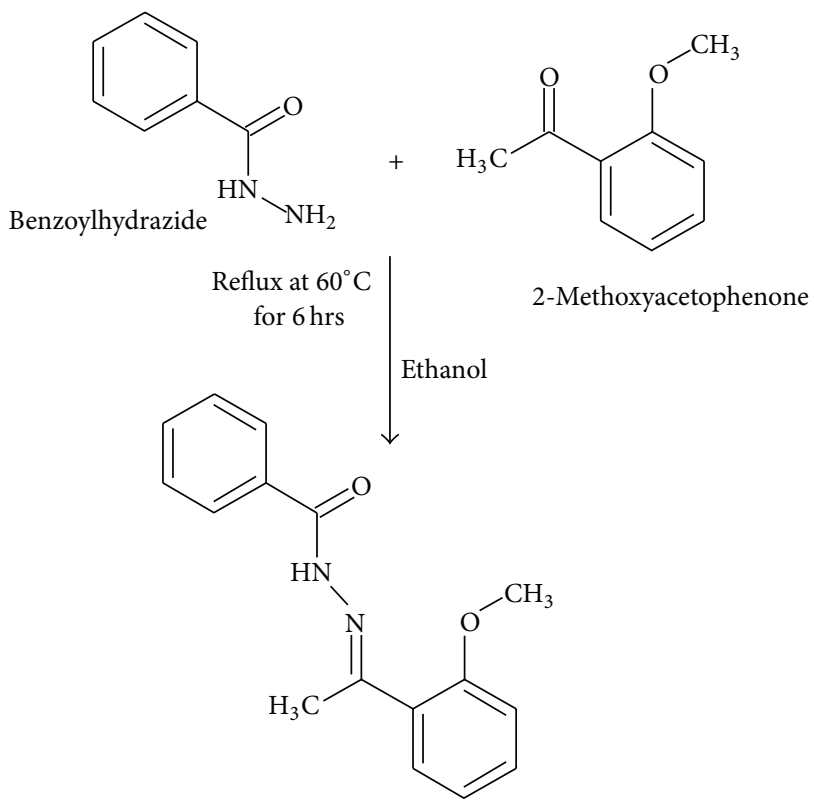

$\left(\mathrm{L}^{4}\right), \mathrm{N}-[(1)-1-(2-$ Methoxyphenyl)ethylidene]benzohydrazide

SCHEMe 1

solution of benzoylhydrazide $(10 \mathrm{mmol}, 1.36 \mathrm{~g})$ was stirred with $(10 \mathrm{~mL})$ of 2 -methyl acetophenone $(10 \mathrm{mmol}, 1.34 \mathrm{~g})$, 4-methyl acetophenone (10 mmol, $1.34 \mathrm{~g}), 2$-methoxy acetophenone $(10 \mathrm{mmol}, 1.50 \mathrm{~g})$, and 4-methoxy acetophenone $(10 \mathrm{mmol}, 1.50 \mathrm{~g})$, respectively. The precipitate was obtained, washed with cold methanol, dried in air, and stored in a $\mathrm{CaCl}_{2}$ desiccator. Yield varied at the range $80-90 \%$. Anal. Calc. for $\mathrm{C}_{16} \mathrm{H}_{16} \mathrm{~N}_{2} \mathrm{O}\left(\mathrm{L}^{2}\right)$ Found: (\%): C, 76.09; H, 6.74, N, 11.09. Calc. (\%): C, 76.07; H, 6.32; N, 11.07. FAB-mass $(\mathrm{m} / \mathrm{z})$ : Calc. 252.33, Found: 252. Anal. Calc. for $\mathrm{C}_{16} \mathrm{H}_{16} \mathrm{~N}_{2} \mathrm{O}\left(\mathrm{L}^{3}\right)$. Calc. (\%): C, 76.07; H, 6.32; N, 11.07. Found (\%): C, 76.09; H, 6.34; N, 11.09. FAB-mass $(\mathrm{m} / \mathrm{z})$ Calc. 252.33, Found: 252. Anal. Calc. for $\mathrm{C}_{16} \mathrm{H}_{16} \mathrm{~N}_{2} \mathrm{O}_{2}$ (L $\mathrm{L}^{4}$ ). Found: C, 71.50; H, 5.91, N, 10.40; Calc. (\%): C, 71.48; H, 5.40; N, 10.38. FAB-mass $(\mathrm{m} / \mathrm{z})$ : Calc. 268.33 . Found: 268. Analc. Calc. for $\mathrm{C}_{16} \mathrm{H}_{16} \mathrm{~N}_{2} \mathrm{O}_{2}\left(\mathrm{~L}^{5}\right)$ Found: (\%) C, 71.55; H, 5.96, N, 10.43. Calc. (\%): C, 71.50; H, 5.91; N, 10.40. FAB-mass $(m / z)$ : Calc. 268.33, Found. 268. 
2.3. Synthesis of $\left[\mathrm{Ni}\left(\mathrm{L}^{1}\right)_{2}\right]\left(\mathrm{ClO}_{4}\right)_{2}(\mathbf{1}) ; \quad\left[\mathrm{Ni}\left(\mathrm{L}^{2}\right)_{2}\right]\left(\mathrm{ClO}_{4}\right)_{2}(2)$; $\left[\mathrm{Ni}\left(\mathrm{L}^{3}\right)_{2}\right]\left(\mathrm{ClO}_{4}\right)_{2}(3) ; \quad\left[\mathrm{Ni}\left(\mathrm{L}^{4}\right)_{2}\right]\left(\mathrm{ClO}_{4}\right)_{2}(4) ; \quad$ and $\left[\mathrm{Ni}\left(\mathrm{L}^{5}\right)_{2}\right]$ $\left(\mathrm{ClO}_{4}\right)_{2}(5)$. All the present complexes were synthesized by following general procedure. The $2: 1$ equimolar ratio to a $\mathrm{MeOH}$ Solution $(20 \mathrm{~mL})$ of $\mathrm{NiCl}_{2} \cdot 6 \mathrm{H}_{2} \mathrm{O}(1.0 \mathrm{mmol}, 0.24 \mathrm{~g})$, a $\mathrm{MeOH}$ solution of Schiff bases $\mathrm{L}^{1}(2.0 \mathrm{mmol}, 0.27 \mathrm{~g}), \mathrm{L}^{2}$ $(2.0 \mathrm{mmol}, 0.50 \mathrm{~g}), \mathrm{L}^{3}(2.0 \mathrm{mmol}, 0.50 \mathrm{~g}), \mathrm{L}^{4}(2.0 \mathrm{mmol}$, $0.53 \mathrm{~g})$, and $\mathrm{L}^{5}(2.0 \mathrm{mmol}, 0.53 \mathrm{~g})$, respectively, was added with stirring for $30 \mathrm{~min}$ at $25^{\circ} \mathrm{C}$. A MeOH solution $(10 \mathrm{~mL})$ of $\mathrm{NaClO}_{4}(2.0 \mathrm{mmol}, 0.25 \mathrm{~g})$ was added for another $30 \mathrm{~min}$ at RT. Complexes that are green (1), light green (2) and (3), and red colors (4) and (5) microcrystalline solid deposited were collected by filtration and washed with $\mathrm{MeOH}$. The obtained solid was dried in air and stored in a $\mathrm{CaCl}_{2}$ desiccator at RT. Yield varied at the range $80-85 \%$. Anal. Calc. for $\mathrm{C}_{14} \mathrm{H}_{16} \mathrm{~N}_{4} \mathrm{Cl}_{2} \mathrm{NiO}_{10}$ (1): Calc. (\%) C, 31.75; H, 3.02; N, 10.5 . Found (\%): C, 31.70; H, 3.00; N, 10.5. FAB-mass $(\mathrm{m} / \mathrm{z})$ : Calc. 529.01; Found 530. Anal. Calc. for $\mathrm{C}_{32} \mathrm{H}_{32} \mathrm{~N}_{4} \mathrm{Cl}_{2} \mathrm{NiO}_{10}(2)$ : Calc. (\%): C, 50.43; H, 4.20; N, 7.35. Found (\%): C, 50.38; H, 4.18; N, 7.30. FAB-mass $(\mathrm{m} / \mathrm{z})$ : Calc. 761.37; Found: 761. Anal. Calc. for $\mathrm{C}_{32} \mathrm{H}_{32} \mathrm{~N}_{4} \mathrm{Cl}_{2} \mathrm{NiO}_{10}$ (3): Calc. (\%): C, 50.40; $\mathrm{H}, 4.28 ; \mathrm{N}, 7.30$. Found (\%): C, 50.42; H, 4.16; N, 7.25. FAB-mass $(\mathrm{m} / \mathrm{z})$ : Calc. 761.37; Found: 761. Anal. Calc. for $\mathrm{C}_{32} \mathrm{H}_{32} \mathrm{~N}_{4} \mathrm{Cl}_{2} \mathrm{NiO}_{12}$ (4); Calc. (\%): C, 48.40; H, 4.03; N, 7.05. Found (\%): C, 48.35; H, 4.01; N, 7.02. FAB-mass $(\mathrm{m} / \mathrm{z}$ ): Calc. 793.37; Found: 793. Anal. Calc. for $\mathrm{C}_{32} \mathrm{H}_{34} \mathrm{~N}_{4} \mathrm{Cl}_{2} \mathrm{NiO}_{12}(\mathbf{5})$; Calc (\%): C, 48.38; H, 4.01; N, 7.03. Found (\%): C, 48.33; H, 4.00; N, 7.01. FAB-mass $(\mathrm{m} / \mathrm{z})$ : Calc. 793.37; Found: 793.

\section{Results and Discussion}

3.1. Synthesis and Characterization. The mononuclear complexes prepared in high yield by reacting nickel (II) salt with bidentate Schiff bases in 2:1 molar ratio to give complexes of general composition $\left[\mathrm{Ni}(\mathrm{A})_{2}\right]$. The reactions proceed in the following manner (Scheme 2):

$$
\mathrm{Ni}^{2}++2 \mathrm{~A} \longrightarrow\left[\mathrm{Cu}(\mathrm{A})_{2}\right]
$$

where $\mathrm{A}=\mathrm{L}^{1}, \mathrm{~L}^{2}, \mathrm{~L}^{3}, \mathrm{~L}^{4}$, and $\mathrm{L}^{5}$. The Schiff base ligands were prepared by refluxing equimolar quantities of benzoylhydrazine and 4-methoxyacetophenone; 4-methoxyacetophenone; 2-methoxyacetophenone; 2-methoxyacetophenone, respectively, in ethanol for 4-6h. Complexes are green (1), light green (2) and (3), red colour (4) and (5) are stable in air, partially soluble in water but soluble in most of organic solvent. These complexes were prepared in good yields and characterized by microanalysis. All the complexes decompose between 170 and $280^{\circ} \mathrm{C}$. The molar conductivity values in DMSO solutions are very low $\left(3.51-12.32 \Omega^{-1} \mathrm{~cm}^{2} \mathrm{~mol}^{-1}\right)$ of $10^{-3} \mathrm{M}$ solutions, at room temperature indicate that they are nonelectrolytes [22]. The value of $\mu_{\text {eff }}$ at room temperature of the Ni (II) complexes is 2.94 B.M. for (1), 2.69 B.M. for (2), 2.73 B.M. for (3), 2.83 B.M. for (4), and 2.92 B.M. for (5), suggesting that this is essentially diamagnetic. For the $\mathrm{d}^{8}$ electronic configuration, diamagnetism generally implies that the metal has square planar configuration [23].
3.2. Spectroscopic Study. The room temperature ligand field spectra (electronic spectra) of these complexes have been recorded in $100 \%$ DMSO solution at $25^{\circ} \mathrm{C}$. In present $\mathrm{Ni}$ (II) complexes, the highest energy d-d energy transition from the lower lying fully occupied $3 \mathrm{~d}_{x^{2}-y^{2}}$ orbital to the upper empty $3 \mathrm{~d}_{x y}$ orbital ("B $\leftarrow A$ " transition) at $405 \pm 5 \mathrm{~nm}$ is obscured by the MLCT transition. The other three lower energy $\mathrm{d}$ - $\mathrm{d}$ transitions from the occupied $3 \mathrm{~d}_{z}{ }^{2}, 3 \mathrm{~d}_{x z}$, and $3 \mathrm{~d}_{y z}$ orbitals to the empty $3 \mathrm{~d}_{x y}$ orbital $\left({ }^{1} \mathrm{~B} \leftarrow{ }^{1} \mathrm{~A},{ }^{1} \mathrm{~B} \leftarrow{ }^{1} \mathrm{~A}\right.$, and ${ }^{1} \mathrm{~A} \leftarrow{ }^{1} \mathrm{~A}$ transition, resp.) are less intense, appear as a broad envelope around at the range $615 \pm 5 \mathrm{~nm}$ region, and are typical of square planar monoligated nickel (II) complexes [24]. In addition, MLCT transition is located at the range 420 $\pm 5 \mathrm{~nm}$. The azomethine $(-\mathrm{HC}=\mathrm{N}-)$ characteristic band in the IR for the free ligand was observed at $\sim 1650 \pm 5 \mathrm{~cm}^{-1}$. The IR-spectra of the complexes show coordination $\mathrm{C}=\mathrm{N}$ bonds [25] in the range of $1602-1628$ and of $460-490 \mathrm{~cm}^{-1}$. A strong band, observed at ca. $1205-1329 \mathrm{~cm}^{-1}$ is assigned to coordination through phenolic oxygen [26]. In addition, these complexes show strong bands at $1053 \mathrm{~cm}^{-1}$ and $1083 \mathrm{~cm}^{-1}$ indicating the presence of $\mathrm{ClO}_{4}$ groups [27] in agreement with their noncoordinating character. Vibrations at $\sim 460$ weak (and expected below $400 \mathrm{~cm}^{-1}$, out of our measuring limit) can be attributed to $\mathrm{M}-\mathrm{O}$ and $\mathrm{M}-\mathrm{N}$ vibrations [28].

3.3. Electrochemical Studies. Electroactivity of the complexes was studied in DMSO with $0.1 \mathrm{M} \mathrm{NaClO}_{4}$ as supporting electrolyte using cyclic voltammetry at a platinum working electrode. "Supplementary material" and redox potential values are given in Table 1 . The redox processes assigned as $\mathrm{Ni}$ (II)/Ni (I) couples are fully irreversible [29]. The voltammograms of these complexes consist of two well-separated peaks, one cathodic potential $\left(E_{\mathrm{pc}}\right)$ and one anodic potential $\left(E_{\mathrm{pa}}\right)$. In these complexes reduction waves are observed at more negative potentials. In these cases, the peak potential differences increase as the scan rate increases. Constancy of $E^{\prime}{ }_{0}$ shows that in all the cases both peaks are complementary to each other. The peak current ratio $I_{\mathrm{pa}} / I_{\mathrm{pc}}$ is less than unity showing that the electron transfer reaction is followed by a chemical reaction (EC mechanism) [30].

3.4. Superoxide Dismutase Activity. The SOD activities for the complexes were measured. Superoxide was enzymatically supplied from alkaline DMSO and SOD activity was evaluated by the NBT assay [31] following the reduction of NBT to $\mathrm{MF}^{+}$kinetically at $560 \mathrm{~nm}$. These complexes exhibit significant catalytic activity towards the dismutation of superoxide anions. The concentration causing 50\% inhibition of NBT reduction is $\mathrm{IC}_{50}$. The SOD activity of $\left[\mathrm{Ni}\left(\mathrm{L}^{1}\right)_{2}\right]\left(\mathrm{ClO}_{4}\right)_{2}(\mathbf{1})$ was shown in Figure 1. The observed $\mathrm{IC}_{50}$ values of the nickel (II) complexes (50 for 1, 40 for 2, 49 for 3,41 for 4, and 48 for $5 \mu \mathrm{mol} \mathrm{dm}{ }^{-3}$ ) are higher than the value exhibited by the native enzyme $\left(\mathrm{IC}_{50}=0.04 \mu \mathrm{mol} \mathrm{dm}{ }^{-3}\right.$ ) on a molar base (note that the smaller the $\mathrm{IC}_{50}$ value, the higher the SOD activity). The observed $\mathrm{IC}_{50}$ values of the present complexes are comparable to reported values [32] for nickel (II) (Table 2). The catalytic activity of NiSOD [6], however, 

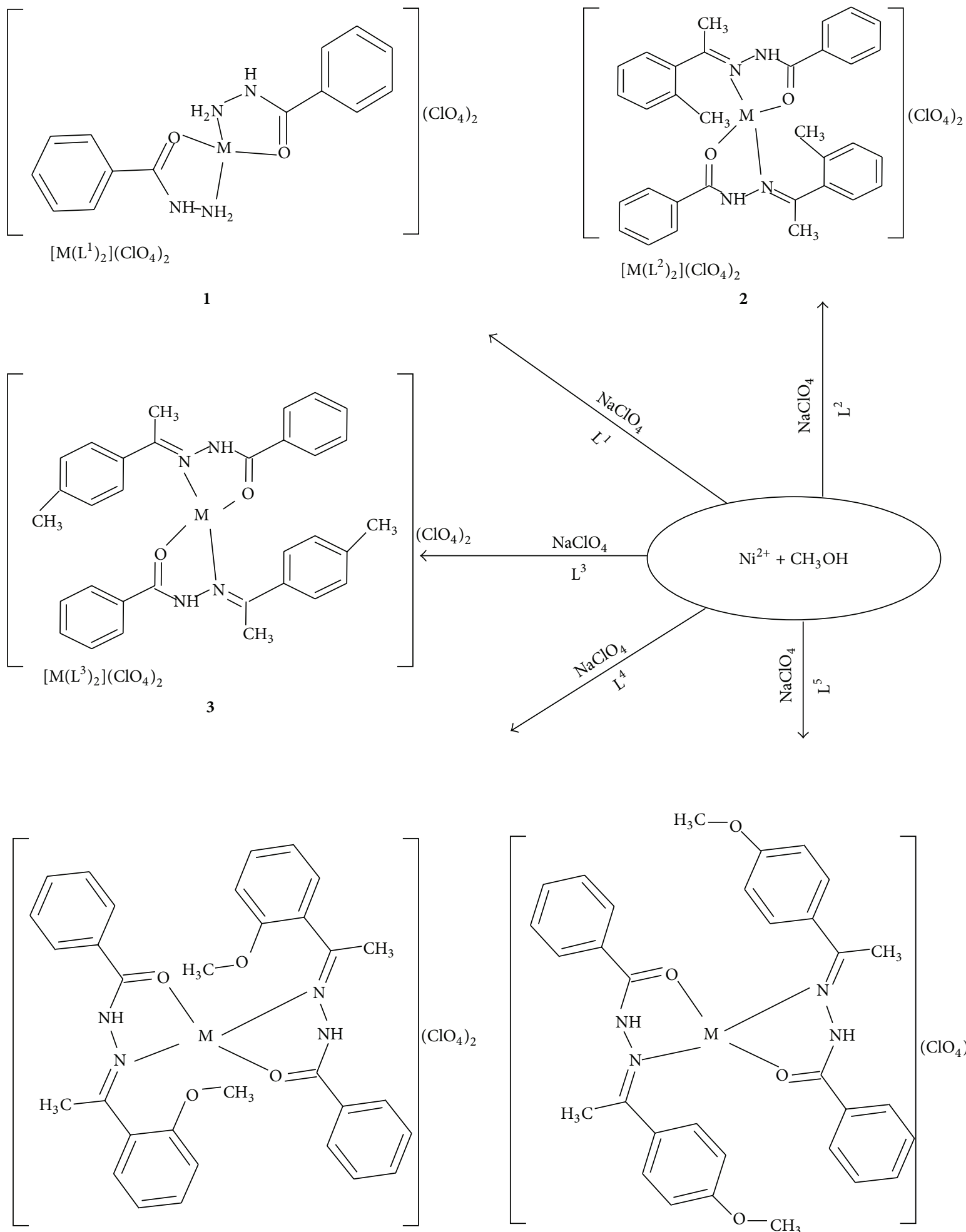

$\left[\mathrm{M}\left(\mathrm{L}^{4}\right)_{2}\right]\left(\mathrm{ClO}_{4}\right)_{2}$,

4

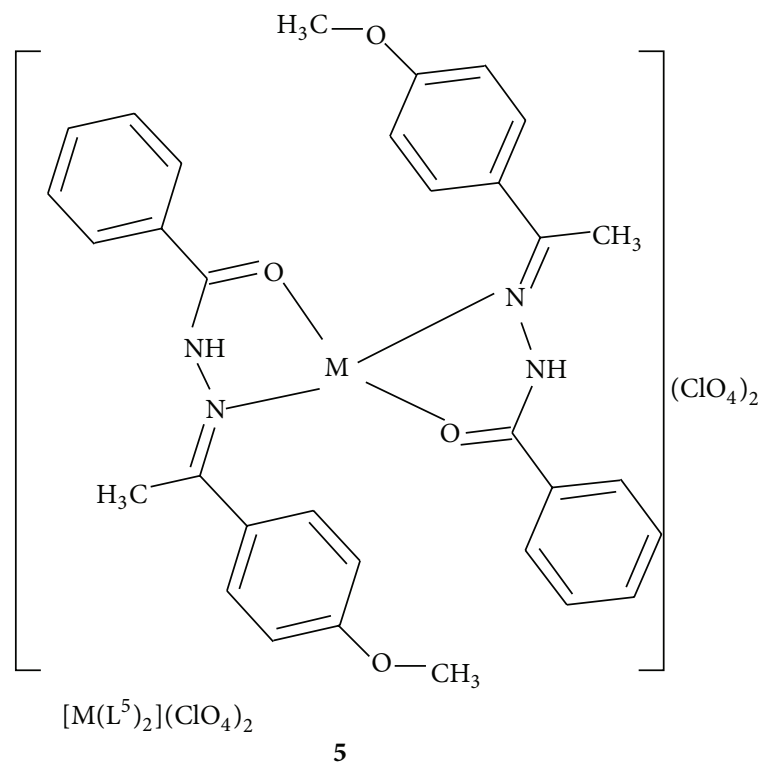

where $\mathrm{M}=\mathrm{Ni}$

Scheme 2 
TABLE 1: Cyclic voltammetry data for $1 \mathrm{mM}$ solution of the nickel (II) complexes in DMSO containing $0.1 \mathrm{M} \mathrm{NaClO}_{4}$ as supporting electrolyte.

\begin{tabular}{|c|c|c|c|c|c|c|c|}
\hline Scan rate $(\mathrm{m} \mathrm{v} / \mathrm{s})$ & $E_{\mathrm{pc}}(\mathrm{mv})$ & $I_{\mathrm{pc}}(\mu \mathrm{A})$ & $E_{\mathrm{pa}}(\mathrm{mv})$ & $I_{\mathrm{pa}}(\mu \mathrm{A})$ & $\Delta E_{p}$ & $E_{0}^{\prime}$ & $I_{\mathrm{pa}} / I_{\mathrm{pc}}(\mu \mathrm{A})$ \\
\hline $\begin{array}{l}{\left[\mathrm{Ni}\left(\mathrm{L}^{1}\right)_{2}\right]\left(\mathrm{ClO}_{4}\right)_{2}(\mathbf{1})} \\
1009\end{array}$ & -637 & 1.148 & -552 & 0.682 & 115 & 609 & 0.594 \\
\hline 200 & -683 & 0.895 & -560 & 0.485 & 123 & 621 & 0.541 \\
\hline $\begin{array}{l}{\left[\mathrm{Ni}\left(\mathrm{L}^{2}\right)_{2}\right]\left(\mathrm{ClO}_{4}\right)_{2}(2)} \\
100\end{array}$ & -790 & 1.120 & -672 & 0.755 & 118 & 731 & 0.674 \\
\hline 200 & -793 & 1.722 & -668 & 1.549 & 125 & 730 & 0.899 \\
\hline $\begin{array}{l}{\left[\mathrm{Ni}\left(\mathrm{L}^{3}\right)_{2}\right]\left(\mathrm{ClO}_{4}\right)_{2}(3)} \\
100\end{array}$ & -685 & 1.148 & -552 & 0.916 & 133 & 618 & 0.797 \\
\hline 200 & -688 & 1.118 & -570 & 1.044 & 118 & 629 & 0.933 \\
\hline $\begin{array}{l}{\left[\mathrm{Ni}\left(\mathrm{L}^{4}\right)_{2}\right]\left(\mathrm{ClO}_{4}\right)_{2}(4)} \\
100\end{array}$ & -685 & 1.140 & -548 & 0.680 & 137 & 616 & 0.596 \\
\hline 200 & -690 & 0.790 & -564 & 0.482 & 126 & 628 & 0.610 \\
\hline $\begin{array}{l}{\left[\mathrm{Ni}\left(\mathrm{L}^{5}\right)_{2}\right]\left(\mathrm{ClO}_{4}\right)_{2}(\mathbf{5})} \\
100\end{array}$ & -782 & 1.125 & -670 & 0.756 & 112 & 726 & 0.672 \\
\hline 200 & -787 & 1.925 & -664 & 1.550 & 122 & 726 & 0.805 \\
\hline
\end{tabular}

$\Delta E_{p}=E_{\mathrm{pa}}-E_{\mathrm{pc}} ; E_{0}^{\prime}=\left(E_{\mathrm{pa}}+E_{\mathrm{pc}}\right) / 2$.

TABLE 2: Superoxide dismutase activity of some nickel (II) complexes.

\begin{tabular}{lccr}
\hline Serial number & Complexes & $\mathrm{IC}_{50}\left(\mu \mathrm{mol} \mathrm{dm}^{-3}\right)$ & Reference \\
\hline$(1)$ & {$[\mathrm{Ni}($ tren $)($ Phen $)]\left(\mathrm{ClO}_{4}\right)_{2}$} & 40 & {$[17]$} \\
$(2)$ & {$[\mathrm{Ni}(\mathrm{tren})($ bipy $)]\left(\mathrm{ClO}_{4}\right)_{2}$} & 48 & {$[17]$} \\
$(3)$ & {$[\mathrm{Ni}(\mathrm{SAA})(\mathrm{PMDT})] \cdot 2 \mathrm{H}_{2} \mathrm{O}$} & 43 & {$[17]$} \\
$(4)$ & {$[\mathrm{Ni}(\mathrm{SAA})](\mathrm{TPTZ})$} & 65 & {$[17]$} \\
$(5)$ & {$[\mathrm{Ni}(\mathrm{BPSE})]\left(\mathrm{BF}_{4}\right)$} & 48 & {$[24]$} \\
$(6)$ & {$\left[\mathrm{Ni}(5-\mathrm{BST})\left(\mathrm{CH}_{3} \mathrm{OH}\right)\right] \mathrm{ClO}_{4}$} & 50 & This work \\
$(7)$ & {$\left[\mathrm{Ni}\left(\mathrm{L}^{1}\right)_{2}\right]\left(\mathrm{ClO}_{4}\right)_{2}(\mathbf{1})$} & 40 & This work \\
$(8)$ & {$\left[\mathrm{Ni}\left(\mathrm{L}^{2}\right)_{2}\right]\left(\mathrm{ClO}_{4}\right)_{2}(\mathbf{2})$} & 49 & This work \\
$(9)$ & {$\left[\mathrm{Ni}\left(\mathrm{L}^{3}\right)_{2}\right]\left(\mathrm{ClO}_{4}\right)_{2}(\mathbf{3})$} & 41 & This work \\
$(10)$ & {$\left[\mathrm{Ni}\left(\mathrm{L}^{4}\right)_{2}\right]\left(\mathrm{ClO}_{4}\right)_{2}(\mathbf{4})$} & 48 & This work \\
$(11)$ & {$\left[\mathrm{Ni}\left(\mathrm{L}^{5}\right)_{2}\right]\left(\mathrm{ClO}_{4}\right)_{2}(\mathbf{5})$} & &
\end{tabular}

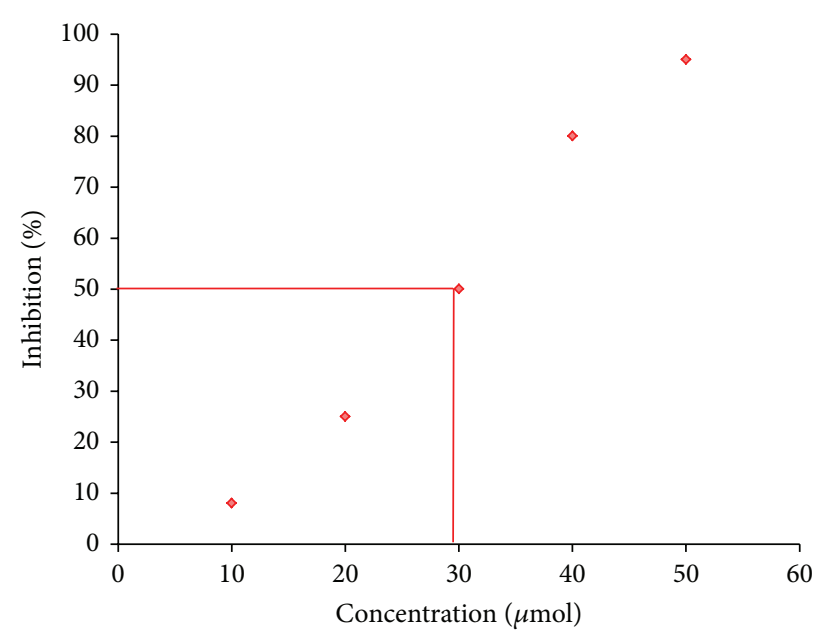

FIGURE 1: Superoxide dismutase activity of $\left[\mathrm{Ni}\left(\mathrm{L}^{1}\right)_{2}\right]\left(\mathrm{ClO}_{4}\right)_{2}(\mathbf{1})$. 


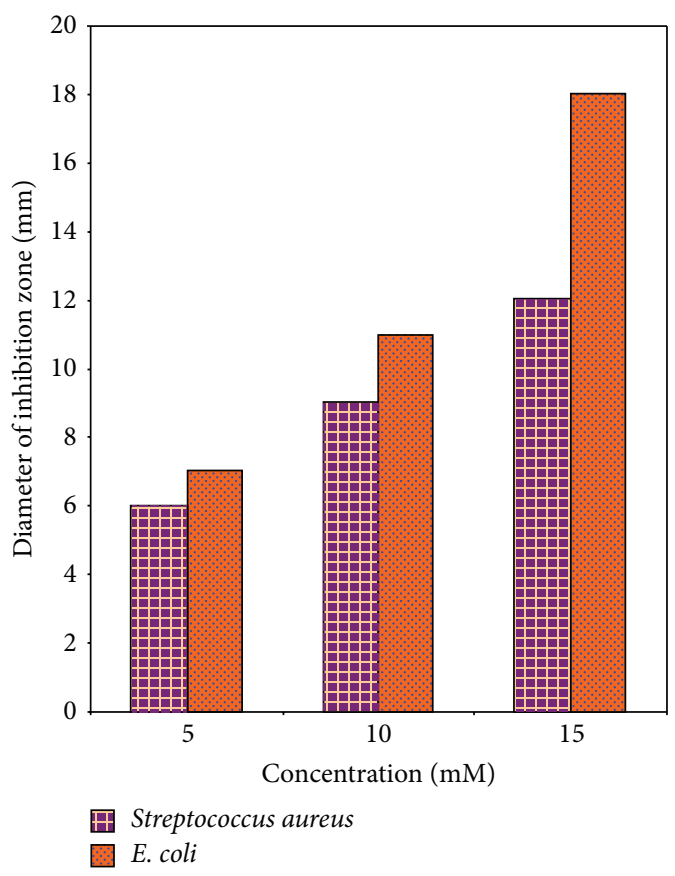

Figure 2: Antibacterial activity of complex $\left[\mathrm{Ni}\left(\mathrm{L}^{1}\right)_{2}\right]\left(\mathrm{ClO}_{4}\right)_{2}(\mathbf{1})$.

is on the same high level as that of $\mathrm{Cu}-\mathrm{ZnSOD}$ at about $10^{9}$ $\left(\mathrm{mol} \mathrm{L}^{-1}\right)^{-1} \mathrm{~S}^{-1}$ per metal center.

3.5. Antimicrobial Activity. The in vitro antimicrobial (antibacterial) activities of these complexes were tested using paper disc diffusion method; the chosen strains were $\mathrm{G}(+)$ Streptococcus aureus and Escherichia coli. Three concentrations of the present complexes were taken, that is, $5 \mathrm{mM}, 10 \mathrm{mM}$, and $15 \mathrm{mM}$. Paper disc were prepared and dipped with the help of these different solution. The susceptibility of the certain strains of bacterial towards the nickel (II) was determined by measuring the size of inhibition diameter. The growth inhibitory effects were observed against all the bacterial/fungal strains. Both bacteria are pathogens for humans, which cause dysentery and food poisoning, respectively. Complexes $\mathbf{1}$ and $\mathbf{2}$ were tested for their antibacterial and antifungal activity. The antibacterial activity of $\left[\mathrm{Ni}\left(\mathrm{L}^{1}\right)_{2}\right]\left(\mathrm{ClO}_{4}\right)_{2} \mathbf{1}$ is graphically presented in Figure 2. Results of these antimicrobial and antifungal assessments of complexes are presented in Tables 3 and 4 . The area of zone of inhibition is less in the concentration of $5 \mathrm{mM}$ in both microorganisms and more in $15 \mathrm{mM}$ concentration. This kind of observation is suggestive of that these complexes are effective against both pathogens. In case of complex 1 diameter of inhibition zone $(20 \mathrm{~nm})$ is highest for E.coli. It was noted that complex $\mathbf{1}$ was more effective against $E$. coli than Streptococcus aureus. Similar observations were found for complex 2. Among fungal species, two isolates were taken into consideration and were Aspergillus and Penicillium sp.; similar trends were observed as in the case of bacteria. It was noted that Penicillium sp. was highly susceptible against complex 1. Another fungi Aspergillus sp. showed least effectiveness against complex 2 but comparatively more
TABLE 3: Antibacterial activity of nickel (II) complexes 1 and 2.

\begin{tabular}{lcc}
\hline \multirow{2}{*}{ Complexes $(\mathrm{mM})$} & \multicolumn{2}{c}{ Diameter of inhibition zone (in mm) } \\
& Streptococcus aureus & E. coli \\
\hline$\left[\mathrm{Ni}\left(\mathrm{L}^{1}\right)_{2}\right]\left(\mathrm{ClO}_{4}\right)_{2}(\mathbf{1})$ & 6 & 7 \\
5 & 9 & 11 \\
10 & 12 & 18 \\
15 & & \\
{$\left[\mathrm{Ni}\left(\mathrm{L}^{2}\right)_{2}\right]\left(\mathrm{ClO}_{4}\right)_{2}(2)$} & 4 & 6 \\
5 & 7 & 10 \\
10 & 13 & 15 \\
15 & &
\end{tabular}

TABLE 4: Antifungal activity of nickel (II) complexes $\mathbf{1}$ and 2.

\begin{tabular}{lcc}
\hline Complexes $(\mathrm{mM})$ & $\begin{array}{c}\text { \% Inhibition of spore germination } \\
\text { Aspergillus sp. } \\
\left(\mathrm{mg} \mathrm{mL}^{-1}\right)\end{array}$ & $\begin{array}{c}\text { Penicillium sp. } \\
\left(\mathrm{mg} \mathrm{mL}^{-1}\right)\end{array}$ \\
\hline$\left[\mathrm{Ni}\left(\mathrm{L}^{1}\right)_{2}\right]\left(\mathrm{ClO}_{4}\right)_{2}(\mathbf{1})$ & 10 & 12 \\
5 & 13 & 16 \\
10 & 18 & 20 \\
15 & & \\
{$\left[\mathrm{Ni}\left(\mathrm{L}^{2}\right)_{2}\right]\left(\mathrm{ClO}_{4}\right)_{2}(2)$} & 5 & 8 \\
5 & 7 & 11 \\
10 & 13 & 18 \\
15 & & \\
\hline
\end{tabular}

susceptible towards complex 1 . Similar antimicrobial results were reported by Tarafder et al. [33] and also by Patel School [34] on simple nickel (II) binary and ternary complexes. It is observed from these test that metal chelates have a higher activity than the free ligands such that increased activity of the metal chelated can be explained on the basis of Tweedy's chelation theory [35]. These complexes also disturb the respiratory processes of the cell and thus block the synthesis of protein, which restricts further growth of the organisms.

\section{Conclusion}

Five new nickel (II) complexes, namely, $\left[\mathrm{Ni}\left(\mathrm{L}^{1}\right)_{2}\right]\left(\mathrm{ClO}_{4}\right)_{2} \mathbf{1}$; $\left[\mathrm{Ni}\left(\mathrm{L}^{2}\right)_{2}\right]\left(\mathrm{ClO}_{4}\right)_{2} 2 ; \quad\left[\mathrm{Ni}\left(\mathrm{L}^{3}\right)_{2}\right]\left(\mathrm{ClO}_{4}\right)_{2} 3 ; \quad\left[\mathrm{Ni}\left(\mathrm{L}^{4}\right)_{2}\right]\left(\mathrm{ClO}^{4}\right)_{2} 4$; $\left[\mathrm{Ni}\left(\mathrm{L}^{5}\right)_{2}\right]\left(\mathrm{ClO}_{4}\right)_{2} 5$, have been synthesized and characterized by various physicochemical and spectroscopic techniques. The magnetic and spectroscopic data of complexes 1-5 indicate square planar geometry. The SOD activity of reported complexes in the increasing order $\mathbf{2}<\mathbf{4}<\mathbf{5}<\mathbf{3}<\mathbf{1}$. Complexes $\mathbf{1}$ and $\mathbf{2}$ have shown excellent antibacterial activity against $E$. coli comparable to that of Streptococcus aureus.

\section{Acknowledgments}

Thanks are due to the Head RSIC (SAIF), Central Drug Research Institute, Lucknow, for providing analytical and spectral facilities, and School of Environment Biology, A.P.S. University Rewa (M.P.), India for his help in antibacterial and antifungal screening. Financial assistance from UGC (Bhopal 
F. no. MS-25/101030/07-08/CRO) is thankfully acknowledged.

\section{References}

[1] M. G. B. Drew, S. M. Nelson, and J. Reedijk, "Imidazolate bridged binuclear copper(II) complexes of macrocyclic ligands: electron spin resonance spectra and magnetic susceptibility studies," Inorganica Chimica Acta, vol. 64, pp. L189-L191, 1982.

[2] P. K. Caughlin and S. J. Lippard, "Magnetic, ESR, electrochemical, and potentiometric titration studies of the imidazolatebridged dicopper(II) ion in a binucleating macrocycle," Inorganic Chemistry, vol. 23, no. 10, pp. 1446-1451, 1984.

[3] C. A. Salata, M. T. Youinon, and C. J. Burrows, "(Template)2 synthesis of a dinucleating macrocyclic ligand and crystal structure of its dicopper(II) imidazolate complex," Journal of the American Chemical Society, vol. 111, no. 26, pp. 9278-9279, 1989.

[4] H.-D. Youn, E.-J. Kim, J.-H. Roe, Y. C. Hah, and S.-O. Kang, "A novel nickel-containing superoxide dismutase from Streptomyces spp," Biochemical Journal, vol. 318, no. 3, pp. 889-896, 1996.

[5] J. M. McCord, "Superoxide dismutase in aging and disease: an overview," Methods in Enzymology, vol. 349, pp. 331-341, 2002.

[6] L. W. Oberley and G. R. Buettner, "Role of superoxide dismutase in cancer: a review," Cancer Research, vol. 39, no. 4, pp. 1141-1149, 1979.

[7] W. Bayer, J. Imlay, and I. Fridovich, "Superoxide dismutases," Progress in Nucleic Acid Research and Molecular Biology, vol. 40, pp. 221-253, 1991.

[8] I. Fridovich, "Superoxide radical and superoxide dismutases," Annual Review of Biochemistry, vol. 64, pp. 97-112, 1995.

[9] A. F. Miller and D. L. Sorkin, "Superoxide dismutases: a molecular perspective," Comments on Molecular and Cellular Biophysics, vol. 9, no. 1, pp. 1-48, 1997.

[10] V. P. Singh, A. Katiyar, and S. Singh, "Synthesis, physicochemical investigations and biological studies on $\mathrm{Mn}(\mathrm{II})$, $\mathrm{Co}(\mathrm{II}), \mathrm{Ni}(\mathrm{II}), \mathrm{Cu}(\mathrm{II})$ and $\mathrm{Zn}(\mathrm{II})$ complexes with $p$-amino acetophenone isonicotinoyl hydrazone," Journal of Coordination Chemistry, vol. 62, no. 8, pp. 1336-1346, 2009.

[11] K. K. Narang and V. P. Singh, "Synthesis and characterization of cobalt(II), nickel(II), copper(II) and zinc(II) complexes with acetylacetone bis-benzoylhydrazone and acetylacetone bis-isonicotinoylhydrazone," Transition Metal Chemistry, vol. 18, no. 3, pp. 287-290, 1993.

[12] Y. Ikawa, T. Nagata, and K. Maruyama, "Synthesis and electrochemical properties of dinuclear manganese(II) complexes with octadentate Schiff-base macrocycles. Fine tuning of the redox behavior," Chemistry Letters, vol. 22, no. 6, pp. 1049-1052, 1993.

[13] T. Aono, H. Wada, Y. Aratake, N. Matsumoto, H. Okawa, and Y. Matsuda, "Crystal structure and spin-doublet electron spin resonance of a magnetically coupled $\mathrm{di}(\mathrm{m}$ phenoxo)copper(II)nickel(II) complex," Journal of the Chemical Society, Dalton Transactions, no. 1, pp. 25-29, 1996.

[14] B. Murukan and K. Mohanan, "Synthesis, characterization, electrochemical properties and antibacterial activity of some transiton metal complexes with [(2-hydroxy-1-naphthaldehyde)-3isatin]-bishydrazone," Transition Metal Chemistry, vol. 31, no. 4, pp. 441-446, 2006.

[15] M. El-Behery and H. El-Twigry, "Synthesis, magnetic, spectral, and antimicrobial studies of $\mathrm{Cu}(\mathrm{II}), \mathrm{Ni}(\mathrm{II}) \mathrm{Co}(\mathrm{II}), \mathrm{Fe}(\mathrm{III})$, and UO2(II) complexes of a new Schiff base hydrazone derived from 7-chloro-4-hydrazinoquinoline," Spectrochimica Acta A, vol. 66, no. 1, pp. 28-36, 2007.

[16] R. N. Patel, K. K. Shukla, A. Singh, M. Choudhry, and D. K. Patel, "Synthesis, characterization, crystal structures, and superoxide dismutase activity of copper(II) octahedral complexes containing tri- and monodentate ligands," Journal of Coordination Chemistry, vol. 63, no. 4, pp. 586-599, 2010.

[17] R. N. Patel, M. K. Kesharwani, A. Singh, D. K. Patel, and M. Choudhary, "Syntheses, structures and electrochemical properties of complexes of nickel(II) with triethylenetetramine and bidentate nitrogen donor co-ligands," Transition Metal Chemistry, vol. 33, no. 6, pp. 733-738, 2008.

[18] R. N. Patel, K. K. Shukla, A. Singh et al., "Spectral, structural, and superoxide dismutase activity of some octahedral nickel(II) complexes with tri-tetradentate ligands," Journal of Coordination Chemistry, vol. 63, no. 20, pp. 3648-3661, 2010.

[19] R. G. Bhirud and T. S. Shrivastava, "Synthesis, characterization and superoxide dismutase activity of some ternary copper(II) dipeptide-2,2' -bipyridine, 1,10-phenanthroline and 2,9dimethyl-1,10-phenanthroline complexes," Inorganica Chimica Acta, vol. 179, no. 1, pp. 125-131, 1991.

[20] R. N. Patel, S. P. Rawat, M. Choudhary et al., "Synthesis, structure and biological activities of mixed ligand copper(II) and nickel(II) complexes of $\mathrm{N}^{\prime}$-(1E)-[(5-bromo2-hydroxyphenyl)methylidene]benzoylhydrazone," Inorganica Chimica Acta, vol. 392, pp. 283-291, 2012.

[21] I. Tabushi, Y. Taniguchi, and H. Kato, "Preparation of Calkylated macrocyclic polyamines," Tetrahedron Letters, vol. 18, no. 12, pp. 1049-1052, 1977.

[22] W. J. Geary, "The use of conductivity measurements in organic solvents for the characterisation of coordination compounds," Coordination Chemistry Reviews, vol. 7, no. 1, pp. 81-122, 1971.

[23] R. N. Patel, N. Singh, K. K. Shukla et al., "X-ray, spectral and biological (antimicrobial and superoxide dismutase) studies of oxalato bridged $\mathrm{Cu}(\mathrm{II})-\mathrm{Ni}(\mathrm{II})$ and $\mathrm{Cu}(\mathrm{II})-\mathrm{Zn}$ (II) complexes with pentamethyldiethylenetriamine as capping ligand," Journal of Inorganic Biochemistry, vol. 95, no. 2, pp. 231-237, 2004.

[24] R. N. Patel, K. K. Shukla, A. Singh et al., "Spectroscopic, structural and magnetic studies of nickel(II) complexes with tetra- and pentadentate ligands," Transition Metal Chemistry, vol. 34, no. 2, pp. 239-245, 2009.

[25] R. N. Patel, M. Choudhary, K. K. Shukla, N. Singh, and A. Singh, "Synthesis and characterization of some mixed ligand copper(II) complexes containing ONN donor Schiff base and bidentate ligands," Journal of the Indian Chemical Society, vol. 88, no. 6, pp. 789-794, 2011.

[26] Á. García-Raso, J. J. Fiol, B. Adrover et al., "Reactivity of copper(II) peptide complexes with bioligands (benzimidazole and creatinine)," Polyhedron, vol. 22, no. 25-26, pp. 3255-3264, 2003.

[27] P. F. Rapheal, E. Manoj, and M. R. P. Kurup, “Copper(II) complexes of $\mathrm{N}(4)$-substituted thiosemicarbazones derived from pyridine-2-carbaldehyde: crystal structure of a binuclear complex," Polyhedron, vol. 26, no. 4, pp. 818-828, 2007.

[28] R. N. Patel, N. Singh, and V. L. N. Gundla, "Synthesis, characterization and superoxide dismutase activity of some octahedral nickel(II) complexes," Polyhedron, vol. 26, no. 4, pp. 757-762, 2007.

[29] R. N. Patel, N. Singh, and V. L. N. Gundla, "Synthesis, structure and properties of ternary copper(II) complexes of ONO donor Schiff base, imidazole, 2,2I-bipyridine and 1,10phenanthroline," Polyhedron, vol. 25, no. 17, pp. 3312-3318, 2006. 
[30] R. N. Patel, "Synthesis, characterization, and superoxide dismutase activity of two new copper(II) complexes of benzoylpyridine 4-phenylsemicarbazone," Journal of Coordination Chemistry, vol. 63, no. 7, pp. 1207-1219, 2010.

[31] R. N. Patel, "Structural, magnetic and spectroscopic characterization of two unusual end-on bis( $\mu$-acetato/ $\mu$-nitrato) bridged copper(II) complexes with $\mathrm{N}^{\prime}$-[phenyl(pyridin-2-yl)methylidene]furan-2-carbohydrazide and (2E,4Z)-N,2-dimethylhepta2,4,6-trienamide-1-phenyl-1-pyridin-2-ylmethanimine (1:1) as capping ligands," Inorganica Chimica Acta, vol. 363, pp. 38383846, 2010.

[32] R. N. Patel, N. Singh, K. K. Shukla et al., "Magnetic, spectroscopic, structural and biological properties of mixed-ligand complexes of copper(II) with $\mathrm{N}, \mathrm{N}, \mathrm{N}^{\prime}, \mathrm{N}^{\prime \prime}, \mathrm{N}^{\prime \prime}$-pentamethyldiethylenetriamine and polypyridine ligands," Inorganica Chimica Acta, vol. 357, no. 9, pp. 2469-2476, 2004.

[33] M. T. H. Tarafder, K.-B. Chew, K. A. Crouse, A. M. Ali, B. M. Yamin, and H.-K. Fun, "Synthesis and characterization of $\mathrm{Cu}(\mathrm{II}), \mathrm{Ni}(\mathrm{II})$ and $\mathrm{Zn}(\mathrm{II})$ metal complexes of bidentate NS isomeric Schiff bases derived from S-methyldithiocarbazate (SMDTC): bioactivity of the bidentate NS isomeric Schiff bases, some of their $\mathrm{Cu}(\mathrm{II}), \mathrm{Ni}(\mathrm{II})$ and $\mathrm{Zn}(\mathrm{II})$ complexes and the X-ray structure of the bis[S-methyl- $\beta$-N-(2-furylmethyl)methylenedithiocarbazato]zinc(II) complex," Polyhedron, vol. 21, no. 27-28, pp. 2683-2690, 2002.

[34] R. N. Patel, K. K. Shukla, A. Singh, D. K. Patel, and V. P. Sondhiya, "Structural, spectroscopic, and biological studies of N,O donor Schiff base copper(II) complexes," Journal of Coordination Chemistry, vol. 64, pp. 902-919, 2011.

[35] B. G. Tweedy, "Plant extracts with metal ions as potential antimicrobial agents," Phytopathology, vol. 55, pp. 910-914, 1964. 

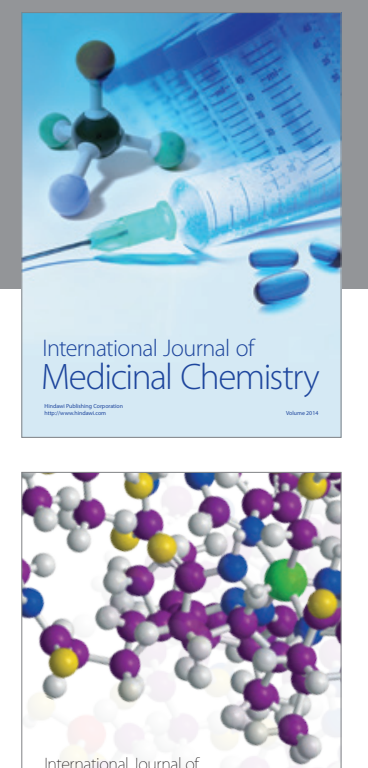

\section{Carbohydrate} Chemistry

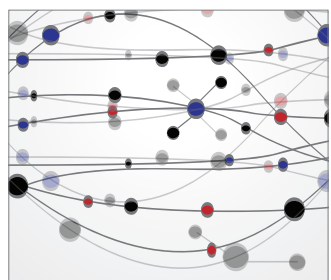

The Scientific World Journal
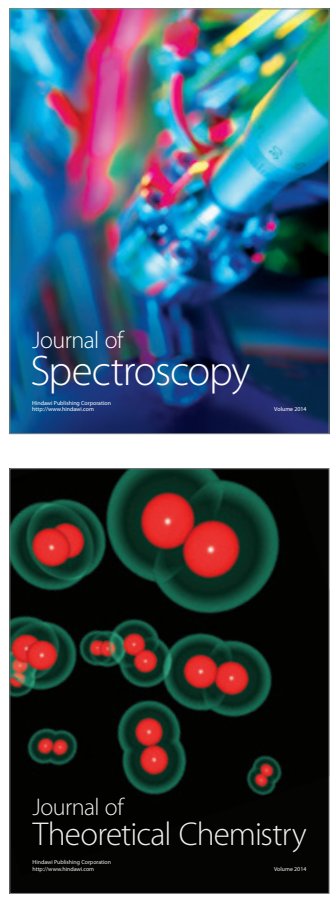
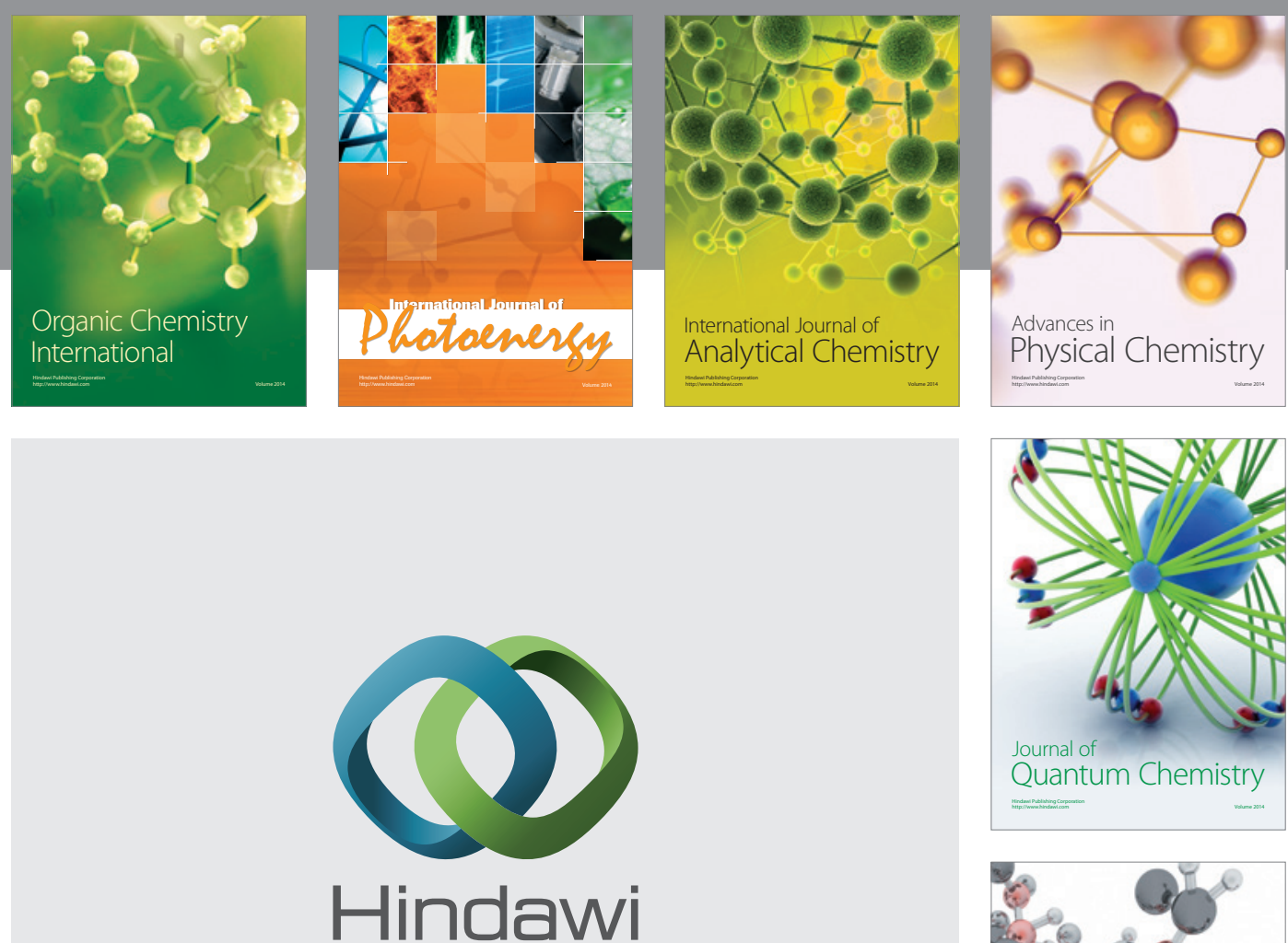

Submit your manuscripts at

http://www.hindawi.com

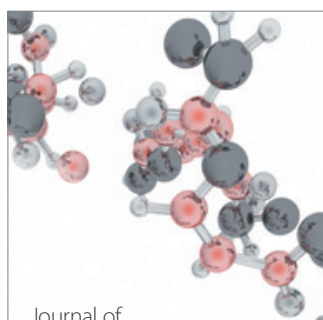

Analytical Methods

in Chemistry

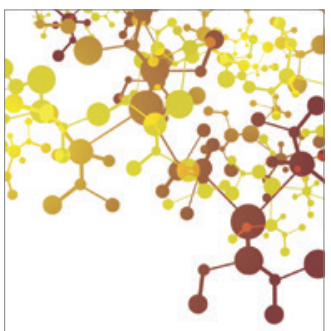

Journal of

Applied Chemistry

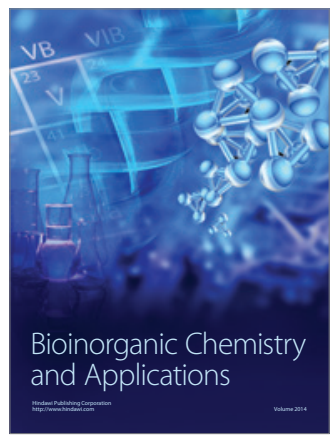

Inorganic Chemistry
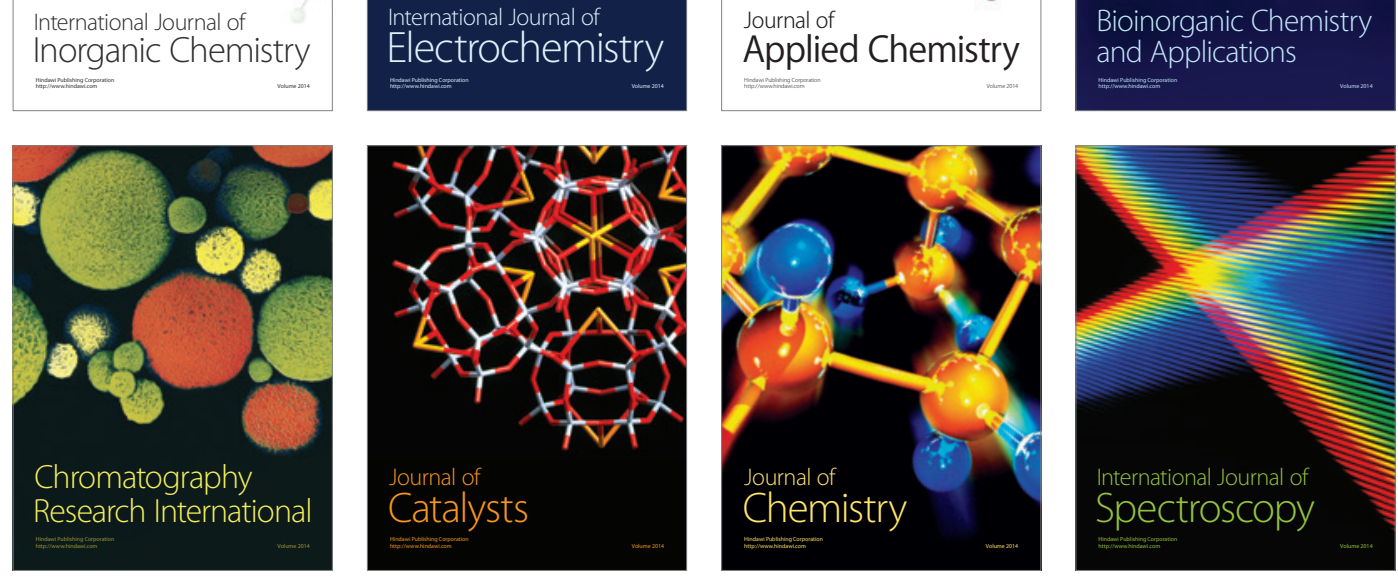